\title{
The pathogenic role of fimbriae of Haemophilus influenzae type $b$ in murine bacteraemia and meningitis
}

\author{
SHUICHI MIYAZAKI, TETSUYA MATSUMOTO, NOBUHIKO FURUYA, KAZUHIRO TATEDA and \\ KEIZO YAMAGUCHI \\ Department of Microbiology, Toho University School of Medicine, 5-21-16, Omori-nishi, Ohta-ku, Tokyo \\ 143-8540, Japan
}

\begin{abstract}
Complement activation and development of murine bacteraemia and meningitis following intranasal instillation of cell-bound fimbriated or non-fimbriated organisms were compared to clarify the role of fimbriae in the pathogenesis of illnesses caused by Haemophilus influenza type b (Hib). In-vitro resistance of non-fimbriate bacteria to the bactericidal effects of normal human serum was at least 400 times greater than that of fimbriate bacteria. The amount of $\mathrm{C} 3$ bound to fimbriate Hib was more than that to non-fimbriate Hib. When mice were infected with fimbriate bacteria, $11.5 \%$ died. When mice were infected with non-fimbriate bacteria, the mean number of viable organisms gradually increased or was constant up to day $7 ; 38.5 \%$ of these mice died. These invivo results were coincident with the in-vitro data. However, the content of polyribosyl ribitol phosphate (PRP) in fimbriate organisms was the same as in non-fimbriate organisms. These results indicate that fimbriate Hib may be less likely to produce bacteraemia and meningitis, correlating with the greater susceptibility to complementmediated bacteriolysis and the lower mortality seen with this type of organism, although fimbriae increase adherence to epithelial cells (mucosal surface).
\end{abstract}

\section{Introduction}

Haemophilus influenzae type $\mathrm{b}$ (Hib) organisms cause both respiratory and systemic infections [1]. Generally, the initial stage in clinical infection by $\mathrm{Hib}$ is attachment to the epithelial cells of the lower respiratory tract, overcoming the mucociliary escalator of the respiratory tract and causing colonisation of the respiratory mucosal surface. This process is mediated by both fimbrial and non-fimbrial adherence factors [2-5]. In invasive Hib disease, organisms appear to penetrate the mucosa and enter the vascular system, leading to bacteraemia and meningitis [6]. The main adhesin of Hib appears to be fimbriae [1]. Antibodies directed against fimbriae diminish bacterial adherence and may prevent infection [7-9]. In contrast to these findings, there have been reports that almost all Hib isolates from infected patients are non-fimbriate $[10,11]$. Infant rats infected with non-fimbriate Hib

Received 14 May 1998; accepted 10 Aug. 1998.

Corresponding author: Dr S. Miyazaki. by various routes were found to have a higher frequency of bacteraemia than animals inoculated with a fimbriate variant $[12,13]$. Thus, the role of fimbriae in the pathogenesis of Hib is not clear.

$H$. influenzae were found intracellularly in adenoid tissues of 10 clinically disease-free children [14]. This shows that $H$. influenzae is an intracellular parasite. It has been demonstrated that $H$. influenzae invades monolayer cells in vitro by a process that is inhibited by cytochalasin $\mathrm{D}$ and colchicine. Accordingly, it seems possible that oropharyngeal epithelial cells carrying cell-bound $H$. influenzae may exfoliate and enter the trachea, thus allowing the bacteria to escape normal host defence mechanisms, establish themselves in the lower respiratory tract and eventually produce infection and disease.

To examine this hypothesis, this laboratory has developed a murine bronchopneumonia model of non-typable $H$. influenzae (NTHI) infection, with cell-bound organisms (CBO) [15]. The Hib bacteraemia and meningitis model established by inoculation of $\mathrm{CBO}$ was considered to be advantageous for studying the virulence factors. 
The aim of the present study was to clarify the role of fimbriae in the pathogenesis of Hib disease. Differences in the quantity of complement bound to fimbriate and non-fimbriate Hib organisms, in the sensitivity of these two groups to complementmediated bacteriolysis and in the mortality rate in murine bacteraemia and meningitis caused by these two organisms were measured to test the hypothesis that Hib fimbriae are associated with complementmediated bactericidal activity and opsonisation.

\section{Materials and methods}

\section{Bacteria}

H. influenzae strains $770235 \mathrm{f}^{-} \mathrm{b}^{+}$and $770235 \mathrm{f}^{+} \mathrm{b}^{+}$ were a gift from Dr L. van Alphen; the source of these strains has been described previously $[5,16]$. The bacteria were cultured overnight in Brain Heart Infusion Broth (Difco, Detroit, MI, USA) supplemented with NAD and haemin (sBHI broth).

Monoclonal antibody (MAb) 6HE8, specific for the fimbriae of $H$. influenzae $770235 \mathrm{f}^{+} \mathrm{b}^{+}$(kindly supplied by $\mathrm{Dr}$ L. van Alphen), was used to confirm expression of the fimbriae in isolates from infected mice by an agglutination test.

A portion of the sBHI culture was inoculated, as a pre-culture, into a fresh sample of the same broth at a final concentration of $5 \%$; the new culture was then incubated for $3 \mathrm{~h}$ at $35^{\circ} \mathrm{C}$. After centrifugation, the bacteria were washed three times with phosphatebuffered saline (PBS) and suspended in Eagle's minimal basal medium (MEM) at a volume similar to that of the original culture (mean viable count $4 \times 10^{8} \mathrm{cfu} / \mathrm{ml}$ ). This suspension was used for the bacterial adherence experiment and quantification of polyribosyl ribitol phosphate (PRP). A portion of the suspension was also diluted 10-fold with RPMI 1640 and this dilution was used in the assay of bacterial killing by normal human serum (NHS).

\section{Tissue culture cells}

Mouse fetal lung (MFL) cells [17] were used for the adherence assay and the preparation of cell-bound organisms. The MFL cell line was cultured in MEM with heat-inactivated fetal calf serum $10 \%$. All media and reagents were from Gibco Laboratories (Grand Island, NY, USA).

\section{Bactericidal effect of NHS}

Sera from three healthy adult volunteers were processed immediately, pooled and stored at $-80^{\circ} \mathrm{C}$ as individual $0.5-\mathrm{ml}$ samples. The haemolytic complement activity of pooled serum was $35 \mathrm{CH}_{50} \mathrm{U} / \mathrm{ml}$. NHS was inactivated at $56^{\circ} \mathrm{C}$ for $30 \mathrm{~min}$. The following absorptions were performed. $H$. influenzae strains $770235 \mathrm{f}^{-} \mathrm{b}^{+}$ and $770235 \mathrm{f}^{+} \mathrm{b}^{+}$from a mid-logarithmic phase broth culture were washed in PBS and suspended in $1 \mathrm{ml}$ of ice-cold NHS to yield $10^{9} \mathrm{cfu} / \mathrm{ml}$. Each suspension was rotated at $5 \mathrm{rpm}$ and $4^{\circ} \mathrm{C}$ for $30 \mathrm{~min}$, after which the serum was separated by centrifugation at $0^{\circ} \mathrm{C}$. The sera absorbed with $H$. influenzae $770235 \mathrm{f}^{-} \mathrm{b}^{+}$and $770235 \mathrm{f}^{+} \mathrm{b}^{+}$were named $\mathrm{NHS}^{\mathrm{F}-}$ and $\mathrm{NHS}^{\mathrm{F}+}$, respectively. Studies on the bactericidal effects of pooled serum were performed in RPMI 1460 medium with serum $10 \%$, to which Hib were added as free bacteria $\left(8 \times 10^{5} \mathrm{cfu} / \mathrm{ml}\right)$. The resulting suspensions were rotated at $5 \mathrm{rpm}$ for $0.5,1$ and $2 \mathrm{~h}$ at $35^{\circ} \mathrm{C}$. After each time interval, the samples were agitated vigorously with glass beads, then plated in duplicate on to chocolate agar to determine the number of viable bacteria. In this experiment, Escherichia coli $\mathrm{JC2}$, sensitive to human serum, was used as a control.

\section{Assay of C3 bound to organisms}

Bacteria cultured overnight on chocolate agar plates were collected and washed three times with PBS. The organisms were then suspended in carbonate buffer, $\mathrm{pH}$ 9.5, at a concentration corresponding to McFarland no. 0.5 . Microtitration plates were coated with this bacterial suspension and incubated for $18 \mathrm{~h}$ at $4^{\circ} \mathrm{C}$, after which non-specific binding sites were blocked by incubation with PBS containing bovine serum albumin $1 \% \mathrm{w} / \mathrm{v}$ for $18 \mathrm{~h}$ at $4^{\circ} \mathrm{C}$.

After the plates had been washed with PBS, $100 \mu 1$ of human $\mathrm{C} 3$ solution $(1 \mu \mathrm{g} / \mathrm{ml}$ in blocking buffer; Chemicon Internal, Temecula, CA, USA) were added to each well. The plates were then incubated for $1 \mathrm{~h}$ at $35^{\circ} \mathrm{C}$ and washed with PBS. Goat anti-human C3 serum (Chemicon International), diluted 100-fold with blocking buffer, was then added to each well (100 $\mu \mathrm{l} /$ well $)$. After incubation for $2 \mathrm{~h}$ at $35^{\circ} \mathrm{C}$, the plates were washed with PBS and $100 \mu$ l of alkaline phosphataseconjugated goat IgG (Chemicon International), diluted 500 -fold with blocking buffer, were added to each well. The plates were then incubated for $2 \mathrm{~h}$ at $35^{\circ} \mathrm{C}$. After the plates had been washed, $100 \mu \mathrm{l}$ of substrate (phenylphosphoric acid $4.5 \mathrm{mmol} / \mathrm{L}$ and 4-aminoantipyrine $2.0 \mathrm{mmol} / \mathrm{L}$ in $0.025 \mathrm{M}$ carbonate buffer, $\mathrm{pH}$ 10.2) were added to each well and the plates were incubated for $30 \mathrm{~min}$ at $35^{\circ} \mathrm{C}$. Finally, $50 \mu \mathrm{l}$ of sodium metaperiodate $0.8 \%$ solution were added to each well and the optical density was read at $490 \mathrm{~nm}\left(\mathrm{OD}_{490}\right)$.

\section{Quantification of PRP in fimbriate and non- fimbriate organisms}

The cells suspended in $3 \mathrm{ml}$ of PBS were lysed by sonication to release PRP. Samples were then diluted and PRP content was assayed by ELISA, with burro antiserum to PRP (kindly supplied by Dr J. Robbins), rabbit anti-Hib serum (kindly supplied by $\mathrm{Dr} H$. Gondaira) and purified PRP (kindly supplied by Dr J. Marshall). Microtitration plates were coated with burro 
antiserum to PRP diluted 1 in 1000 in carbonate buffer, $\mathrm{pH} 9.5$, for $18 \mathrm{~h}$ at $4^{\circ} \mathrm{C}$. Plates were then washed three times with PBS and samples were added to the first row of wells. The first well contained PBS only as a blank and the last well contained purified PRP $50 \mathrm{ng} / \mathrm{ml}$. Doubling dilutions of samples, blank and standard were performed in PBS to fill the rest of the wells on the plate. The plate was incubated for $2 \mathrm{~h}$ at $35^{\circ} \mathrm{C}$ before being washed three times with PBS. Rabbit anti-Hib diluted 1 in 1000 in PBS was added to each of the wells and further incubated for $2 \mathrm{~h}$ at $35^{\circ} \mathrm{C}$. Plates were washed again three times with PBS and $100 \mu \mathrm{l}$ of alkaline phosphatase-conjugated goat IgG (Chemicon Internal), diluted 1000 times with blocking buffer, were added to each well. The plates were then incubated for $2 \mathrm{~h}$ at $35^{\circ} \mathrm{C}$. After washing, $100 \mu \mathrm{l}$ of substrate (phenylphosphoric acid $4.5 \mathrm{mmol} / \mathrm{L}$ and 4aminoantipyrine $2.0 \mathrm{mmol} / \mathrm{L}$ in $0.025 \mathrm{M}$ carbonate buffer, $\mathrm{pH}$ 10.2) were added to each well. After incubation for $30 \mathrm{~min}$ at $35^{\circ} \mathrm{C}, 50 \mu \mathrm{l}$ of $0.8 \%$ sodium metaperiodate solution were added to each well and the $\mathrm{OD}_{490}$ values were read. The experiment was performed five times for each strain.

\section{Adherence of bacteria to epithelial cells}

The bacterial adherence experiment was performed according to a protocol described previously [18]. Briefly, $2 \mathrm{ml}$ of the bacterial suspension were added to a Leighton tube containing a cover slip; tubes were mixed by rotation at $1 \mathrm{rpm}$ and $35^{\circ} \mathrm{C}$. After $40 \mathrm{~min}$, non-adherent bacteria were removed by washing the coverslip five times with PBS. Each coverslip was stained with Giemsa's stain and the number of attached bacteria/50 tissue culture cells was counted with the oil immersion lens.

Bacteria were treated with GM1 by the method of Gilsdorf et al. [19]. GM1 (Sigma) was dissolved in MEM at a final concentration of $0.25 \mu \mathrm{g} / \mathrm{ml}$. Bacterial suspension and GM1 solution were mixed $(2 \mathrm{ml}$ of each) and rotated at $1 \mathrm{rpm}$ and $35^{\circ} \mathrm{C}$. After $60 \mathrm{~min}$, bacteria were collected by centrifugation and suspended in $2 \mathrm{ml}$ of MEM, and the bacterial adherence experiment was carried out as described previously [18].

\section{Preparation of cell-bound organisms}

Cell-bound organisms were prepared according to a protocol described previously [15]. Briefly, the subconfluent monolayer was washed three times with PBS, inoculated with $10 \mathrm{ml}$ of the bacterial suspension described above and gently shaken for $60 \mathrm{~min}$ at $35^{\circ} \mathrm{C}$. Non-adherent bacteria were then removed by washing three times with PBS. Cells with their adherent bacteria, hereafter referred to as cell-bound organisms (CBO), were separated from the tissueculture flask with a scraper and suspended in $2 \mathrm{ml}$ of MEM. To determine the number of viable bacteria, a portion of the CBO suspension was vigorously agitated with glass beads and serial dilutions were plated on enriched (IsoVitalex; Baltimore Biological Laboratories, Baltimore, MD, USA) chocolate agar. Preliminary experiments confirmed that the number of viable bacteria and the MFL cells were in the ranges $(2-5) \times$ $10^{5}$ and $(8-16) \times 10^{5} \mathrm{cfu} / \mathrm{ml}$, respectively.

\section{Experimental infection in mice}

Three days after their airways were impaired by intranasal instillation of $40 \mu \mathrm{l}$ of formalin $1 \%$, 4week-old male Slc/ICR mice (Sankyo Laboservice, Tokyo, Japan) in groups of five mice each, received intranasal instillation of $50 \mu \mathrm{l}$ of the CBO suspension in MEM under ketamine-xylazine anaesthesia [15].

Bacterial numbers in the lower respiratory tract and brain. Under deep ketamine-xylazine anesthaesia, blood samples were obtained by heart puncture with a disposable heparinised syringe on days 1, 3, 5 and 7 after infection. Simultaneously, the lower respiratory tract (lungs and trachea, mean weight $0.2 \mathrm{~g}$ ) and brain (mean weight $0.5 \mathrm{~g}$ ) were removed, homogenised (Homogenizer, Yamato, Tokyo, Japan) and diluted in saline. To determine the number of viable bacteria, a $0.1-\mathrm{ml}$ portion of each sample was plated in duplicate on chocolate agar enriched with IsoVitalex. As the original lung tissue homogenate inhibited growth of $H$. influenzae, but a 10-fold dilution did not, the detectable limit of bacteria in the lower respiratory tract was $5 \times 10^{2} \mathrm{cfu} / \mathrm{g}$ of tissue.

The limit of detection in brain and blood were $2 \times$ $10 \mathrm{cfu} / \mathrm{g}$ of tissue and $1 \times 10 \mathrm{cfu} / \mathrm{ml}$, respectively.

\section{Data analysis}

The data were compared by the Bonferroni multiple comparison test.

\section{Results}

\section{Resistance to serum bactericidal activity}

After incubation with NHS for $2 \mathrm{~h}$, the percentages of survivors among fimbriate and non-fimbriate organisms were $<0.001 \%$ and 0.43 SEM $0.14 \%$, respectively (Table 1). Thus, the resistance of the parent strain to complement-mediated serum bactericidal activity was at least 400 times greater than that of the variant strain. Heat-inactivated human serum exhibited no bactericidal activity against either strain.

This result suggests that the amount of complement bound to the fimbriate strain may be greater than that bound to the non-fimbriate strain. The experiment showed that the amounts of $\mathrm{C} 3$ bound to the nonfimbriate and fimbriate strains, expressed as $\mathrm{OD}_{490}$, were 0.97 SEM 0.13 and 2.22 SEM 0.32 , respectively (Table 1). 
Table 1. Influence of fimbriae on serum bactericidal of $\mathrm{C} 3$ binding activity and PRP content

\begin{tabular}{llll}
\hline & $\begin{array}{l}\text { Resistance to } \\
\text { bactericidal activity* } \\
\text { (Percent of viable counts) }\end{array}$ & $\begin{array}{l}\text { Content of } \\
\text { bound C3 } \\
\left(\mathrm{OD}_{490}\right)\end{array}$ & $\begin{array}{l}\text { Content of } \\
\text { PRP } \\
\left(\mu \mathrm{g} / 1 \times 10^{8} \mathrm{cfu}\right)\end{array}$ \\
\hline $770235 \mathrm{f}^{-} \mathrm{b}^{+}$ & 0.43 SEM 0.14 & 0.97 SEM $0.13^{\dagger}$ & 1.21 SEM 0.27 \\
$770235 \mathrm{f}^{+} \mathrm{b}^{+}$ & $<0.001$ & 2.22 SEM 0.32 & 1.35 SEM 0.33 \\
\hline
\end{tabular}

${ }^{*}$ The viable organisms $2 \mathrm{~h}$ after incubation of organisms plus human serum $10 \%$ at $35^{\circ} \mathrm{C}$ versus viable organisms at start of incubation of the mixture.

${ }^{\dagger} \mathrm{p}<0.01$ versus strain $770235 \mathrm{f}^{+} \mathrm{b}^{+}$by the Bonferroni multiple comparison test

\section{Bactericidal effect of treated NHS}

Both $\mathrm{NHS}^{\mathrm{F}-}$ (normal human serum pre-absorbed with strain $770235 \mathrm{f}^{-} \mathrm{b}^{+}$) and $\mathrm{NHS}^{\mathrm{F}+}$ (normal human serum pre-absorbed with strain $770235 \mathrm{f}^{+} \mathrm{b}^{+}$) had significantly reduced bactericidal effect against $H$. influenzae strain $770235 \mathrm{f}^{+} \mathrm{b}^{+}$, one-tenth of the effect of NHS $(\mathrm{p}<0.01)$ (Fig. 1). Also, there was significantly reduced bactericidal effect against $H$. influenzae strain $770235 \mathrm{f}^{-} \mathrm{b}^{+}(\mathrm{p}$ $<0.01$ ), compared with NHS. There was no significant difference in bactericidal activity against these two strains between $\mathrm{NHS}^{\mathrm{F}-}$ and $\mathrm{NHS}^{\mathrm{F}+}$.

NHS killed fimbriate Hib more effectively than nonfimbriate Hib, and the killing ratio was unchanged after extended incubation.

\section{PRP content in Hib fimbriate and non-fimbriate organisms}

The mean content of cell-associated PRP in strain $770235 \mathrm{f}^{-} \mathrm{b}^{+}$organisms was $1.21 \mu \mathrm{g} / 1 \times 10^{8} \mathrm{cfu}$ and that in strain $770235 \mathrm{f}^{+} \mathrm{b}^{+}$organisms as a counterpart was $1.35 \mu \mathrm{g} / 1 \times 10^{8} \mathrm{cfu}$ (Table 1$)$.

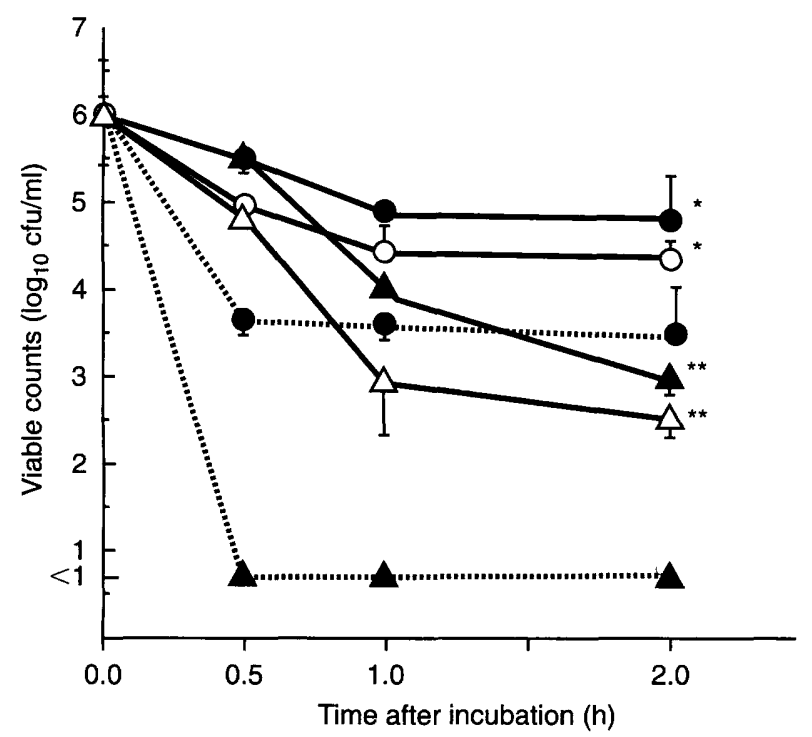

Fig. 1. Bactericidal activity of $\mathrm{NHS}^{\mathrm{F}-}$ and $\mathrm{NHS}^{\mathrm{F}+}$ against fimbriate and non-fimbriate $H$. influenzae: $H$. influenzae strain $770235 \mathrm{f}^{-} \mathrm{b}^{+}$, bactericidal activity of NHS (-๑-), $\mathrm{NHS}^{\mathrm{F}-}(\bullet)$ and $\mathrm{NHS}^{\mathrm{F}+}(0) ; H$. influenzae strain $770235 \mathrm{f}^{+} \mathrm{b}^{+}$, bactericidal activity of NHS $(-\boldsymbol{\Lambda}-), \mathrm{NHS}^{\mathbf{F}-}$ $(\Delta)$ and $\mathrm{NHS}^{\mathrm{F}+}(\triangle)$.

\section{Influence of fimbriae on bacterial adherence}

Previous studies have demonstrated that NTHI organisms show significantly greater adherence to MFL cell monolayers than do Hib organisms [17]. Similarly, fimbriate organisms are significantly more adherent than those without fimbriae [5]. In the present study, the mean numbers of $H$. influenzae strains $770235 \mathrm{f}^{-} \mathrm{b}^{+}$ and $770235 \mathrm{f}^{+} \mathrm{b}^{+}$were 7 and 28 organisms bound to 50 host cells, respectively. Those of strain $770235 \mathrm{f}^{-} \mathrm{b}^{+}$ and $770235 \mathrm{f}^{+} \mathrm{b}^{+}$organisms pre-treated with GM1 were 11 and 12 , respectively. GM1 significantly inhibited the adherence of fimbriate organisms $(p<0.01)$ compared with untreated corresponding organisms.

\section{Influence of fimbriae on murine bacteraemia and meningitis}

To determine the influence of fimbriae on murine bacteraemia and meningitis induced by intranasal instillation of $\mathrm{CBO}$, this study compared a fimbriate variant strain $\left(770235 f^{+} b^{+}\right)$with the non-fimbriate parent strain $\left(770235 f^{-} b^{+}\right)$from which it had been obtained by seven passages in medium containing red blood cells [20].

Viable counts in the lower respiratory organs were $c$. $3 \times 10^{4} \mathrm{cfu} / \mathrm{g}$ of tissue just after inoculation. The number of bacteria in the lungs of mice infected with the fimbriate variant strain decreased daily after infection (Fig. 2). In contrast, the number of bacteria in the lungs of mice infected with the non-fimbriate parent strain fell into two distinct patterns, first visible on the third day following infection. In one group, the number of viable bacteria increased to $>1 \times$ $10^{6} \mathrm{cfu} / \mathrm{g}$ of tissue; in the other group, the number remained constant or decreased.

The mortality rates in this experiment were $38.5 \%$ (10 of 26) in mice infected with non-fimbriate organisms and $11.5 \%$ ( 3 of 26 ) in those infected with fimbriate organisms. This mortality rate agrees with the change in number of viable bacteria in lung tissue following intranasal instillation of CBO. All the isolates from blood or brain of mice infected with either nonfimbriate or fimbriate $\mathrm{Hib}$ were non-fimbriate $\mathrm{Hib}$ organisms by agglutination determination. 


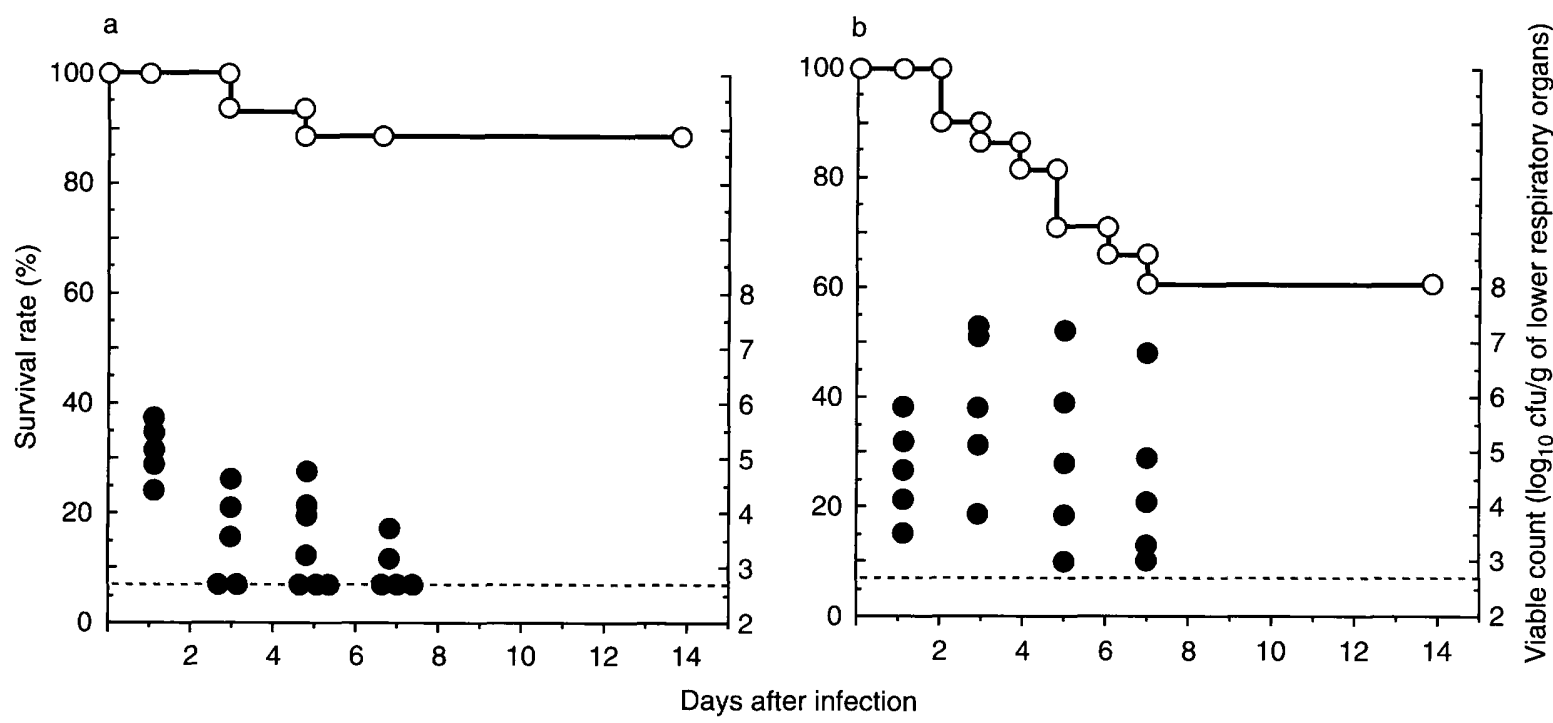

Fig. 2. Survival rate $(\circ)$ and viable counts in lower respiratory organs $(\bullet)$ after infection with $H$. influenzae strains $770235 \mathrm{f}^{+} \mathrm{b}^{+}$(a); $770235 \mathrm{f}^{-} \mathbf{b}^{+}$(b). Infection was by intranasal instillation of CBO with an inoculum size of $(2-3) \times$ $10^{4} \mathrm{cfu} /$ animal. The number of viable bacteria in the lungs was determined at $1,3,5$ and 7 days after infection $(\mathrm{n}=5)$. The dotted line indicates the detectable limit of bacteria in the lower respiratory organs.

\section{Discussion}

It has been demonstrated that fimbriate $\mathrm{Hib}$ are significantly more adherent to cells than non-fimbriate bacteria in vitro [5]. Also, fimbriate organisms show a greater capacity for adherence to mucosal surfaces, although non-fimbriate organisms retain some capacity for colonising the monkey nasopharynx (albeit at reduced densities) [21]. The present study showed a similar phenomenon, and furthermore confirmed that this fimbriae-mediated adherence was inhibited by GM1. On the other hand, Kaplan et al. [12] reported that only three of $50 \mathrm{Hib}$ strains from the nasopharynx of children with $\mathrm{Hib}$ meningitis were fimbriate, as determined by electron microscopy. Also, Pichichero et al. [11] reported that all isolates from Hib meningitis patients did not produce fimbriae as determined by a haemaglutination test. Fimbriae were not uniformly present in Hib strains isolated from either the nasopharynx or CSF, although most isolates examined had the genetic information to express fimbriae [22]. In the light of these facts, the role of fimbriae in the pathogenesis of Hib is ambiguous. The present in-vivo study showed that the mortality rate produced by nonfimbriate $\mathrm{Hib}$ in mice was about three times higher than for fimbriate Hib. As it is well known that $H$. influenzae piliation undergoes phase variation, the present data from the murine model also showed that all blood or brain isolates from animals inoculated with fimbriate Hib were non-fimbriate. These data were consistent with the negative impact of $H$. influenzae piliation on pathogenesis described previously $[11,12]$. Interestingly, the present in-vivo data were consistent with data concerning resistance to bactericidal activity in NHS.
A role for complement in enhancing the clearance of capsulate $H$. influenzae in experimental animal models has been proposed $[23,24]$. The role of fimbriae in the interaction of serum complement with Hib has never been understood. To clarify this point, two invitro methods for complement activation were used in the present study - the determination of complementmediated bacteriolysis in normal human serum and the assessment by ELISA of complement bound to fimbriate and non-fimbriate organisms. The present study showed that the higher susceptibility of fimbriate organisms, compared with non-fimbriate organisms, to bactericidal activity of NHS might be caused by the differences in the level of $\mathrm{C} 3$ bound by those organisms. In addition, $\mathrm{NHS}^{\mathrm{F}-}$ and $\mathrm{NHS}^{\mathrm{F}+}$ could show bactericidal activity against fimbriate and nonfimbriate Hib, although the bactericidal effect of those sera was significantly reduced, compared with NHS. This observation suggests that Hib organisms themselves activate the alternative complement pathway. Quinn et al. [25] demonstrated that Hib organisms could activate the alternative complement pathway without involvement of capsule. Several lines of evidence indicate that both the classical and alternative pathways of complement activation are associated with bactericidal activity against $\mathrm{Hib}$.

The content of PRP was the same in fimbriate and non-fimbriate organisms. This result also supports the conclusion that the enhanced sensitivity of fimbriate organisms to bactericidal activity of NHS is caused by expressed fimbriae. On this point, Gilsdorf et al. [26] reported that MAbs directed against non-fimbriate Hib outer-membrane epitopes bound more to fimbriate Hib than to non-fimbriate $\mathrm{Hib}$, and that non-fimbrial 
antibodies killed fimbriate Hib more effectively than non-fimbriate Hib in complement-dependent bactericidal assays. This result and the data presented here suggest that fimbriae themselves might be required for increased C3 binding and enhanced bactericidal activity. These results support the conclusion that complement can play an important role in determining the clearance of $\mathrm{Hib}$ from blood and that fimbriae are associated with complement-mediated bacteriolysis.

This work was supported in part by Grants-in-Aid for Scientific Research of the Ministry of Education, Science, Sport and Culture of Japan and the Project Research Grant to Toho University School of Medicine.

\section{References}

1. Rubin LG. Pulmonary infections caused by Haemophilus influenzae. In: Chmel HBM, Friedman H (eds) Respiratory infections and immunity. New York, Plenum Press. 1994: 63-83.

2. Farley MM, Stephens DS, Kaplan SL, Mason EO. Pilus- and non-pilus mediated interactions of Haemophilus influenzae type b with human erythrocytes and human nasopharyngeal mucosa. $J$ Infect Dis 1990; 161: 274-280.

3. Loeb MR, Connor E, Penney D. A comparison of the adherence of fimbriated and nonfimbriated Haemophilus influenzae type $\mathrm{b}$ to human adenoids in organ culture. Infect Immun 1988: 56: 484-489.

4. Read RC, Rutman AA, Jeffery PK et al. Interaction of capsulate Haemophilus influenzae with human airway mucosa in vitro. Infect Immun 1992: 60: 3244-3252.

5. van Alphen $\mathrm{L}$, van den Berghe $\mathrm{N}$, Geelen-van den Broek L. Interaction of Haemophilus influenzae with human erythrocytes and oropharyngeal epithelial cells is mediated by a common fimbrial epitope. Infect Immun 1988: 56: 1800-1806.

6. Ward J, Lieberman JM, Cochi SL. Haemophilus influenzae vaccines. In: Plotkin SA, Mortimer EA (eds) Vaccines, 2nd edn. Philadelphia, WB Saunders. 1994: 337-386.

7. Brinton CC, Carter MJ, Derber DB et al. Design and development of pilus vaccines for Haemophilus influenzae diseases. Pediatr Infect Dis $J$ 1989: 8 (1 Suppl): S54-S61.

8. Karasic RB, Beste DJ, To SC et al. Evaluation of pilus vaccines for prevention of experimental otitis media caused by nontypable Haemophilus influenzae. Pediatr Infect Dis $J$ 1989: 8 (1 Suppl): S62-S65.

9. Langermann S, Palaszynski S, Barnhart $\mathrm{M}$ et al. Prevention of mucosal Escherichia coli infection by FimH-adhesin-based systemic vaccination. Science 1997; 276: 607-611.

10. Ahmed K, Ichinose A, Dai TC, et al. Neutrophil response to nontypable Haemophilus influenzae in respiratory infections. Microbiol Immunol 1993; 37: 671-677.

11. Pichichero ME, Loeb M, Anderson P, Smith DH. Do pili play a role in pathogenicity of Haemophilus influenzae type b? Lancet 1982; 2: 960-962.

12. Kaplan SL, Mason EO, Wiedermann BL. Role of adherence in the pathogenesis of Haemophilus influenzae type $\mathrm{b}$ infection in infant rats. Infect Immun 1983; 42: 612-617.

13. Smith AL, Smith DH, Averhill DR, Marino J, Moxon ER. Production of Haemophilus influenzae b meningitis in infant rats by intraperitoneal inoculation. Infect Immun 1973; 8: $278-290$.

14. Forsgren J, Samuelson A, Ahlin A, Jonasson J, Rynnel-Dagöö $\mathrm{B}$, Lindberg A. Haemophilus influenzae resides and multiplies intracellularly in human adenoid tissue as demonstrated by in situ hybridization and bacterial viability assay. Infect Immun 1994; 62: 673-679.

15. Miyazaki S, Nunoya T, Matsumoto T, Tateda K, Yamaguchi K. New murine model of bronchopneumonia due to cell-bound Haemophilus influenzae. J Infect Dis 1997; 175: 205-209.

16. van Schilfgaarde $M$, van Alphen L, Eijk P, Everts V, Dankert J. Paracytosis of Haemophilus influenzae through cell layers of NCI-H292 lung epithelial cells. Infect Immun 1995; 63: 4729-4737.

17. Miyazaki S, Matsunaga T, Kobayashi I, Yamaguchi K, Goto S. The other mediator for adherence of Haemophilus influenzae organisms without involvement of fimbriae Microbiol Immunol 1992; 36: 205-212.

18. Miyazaki S, Leon O, Panos C. Adherence of Streptococcus agalactiae to synchronously growing human cell monolayers without lipoteichoic acid involvement. Infect Immun 1988; 56: $505-512$.

19. Gilsdorf JR, Tucci M, Marrs CF. Role of pili in Haemophilus influenzae adherence to, and internalization by, respiratory cells. Pediatr Res 1996; 39: 343-348.

20. van Alphen L, Poole J, Geelen L, Zanen HC. The erythrocyte and epithelial cell receptors for Haemophilus influenzae are expressed independently. Infect Immun 1987; 55: 2355-2358.

21. Weber A, Harrris K, Lohrke S, Forney L, Smith AL. Inability to express fimbriae results in impaired ability of Haemophilus influenzae b to colonize the nasopharynx. Infect Immun 1991; 59: $4724-4728$.

22. Stull TL, Mendelman PM, Haas JE, Schoenborn MA, Mack $\mathrm{KD}$, Smith AL. Characterization of Haemophilus influenzae type b fimbriae. Infect Immun 1984; 46: 787-796.

23. Crosson FJ, Winklestein JA, Moxon ER. Participation of complement in the nonimmune host defense against experimental Haemophilus influenzae type b septicemia and meningitis. Infect Immun 1976; 14: 882-887.

24. Noel GJ, Katz S, Edelson PJ. Complement-mediated early clearance of Haemophilus influenzae type b from blood is independent of serum lytic activity. $J$ Infect Dis 1988; 157: 85-90.

25. Quinn PH, Crosson FJ, Winklestein JA, Moxon ER. Activation of the alternative complement pathway by Haemophilus influenzae type b. Infect Immun 1977; 16: 400-402.

26. Gilsdorf JR, Tucci M, Forney LJ, Watson W, Marrs CF, Hansen EJ. Paradoxical effect of pilus expression on binding of antibodies by Haemophilus influenzae. Infect Immun 1993; 61: $3375-3381$. 